\title{
Article \\ Understanding Attitudes towards Renewable Energy Technologies and the Effect of Local Experiences
}

\author{
Astrid Buchmayr ${ }^{1,2, *(\mathbb{D})}$, Luc Van Ootegem ${ }^{1}$, Jo Dewulf ${ }^{2} \mathbb{D}$ and Elsy Verhofstadt ${ }^{1}$ (D) \\ 1 Department of Economics, Ghent University, 9000 Ghent, Belgium; Luc.VanOotegem@UGent.be (L.V.O.); \\ Elsy.Verhofstadt@UGent.be (E.V.) \\ 2 Research Group Sustainable Systems Engineering, Department Green Chemistry and Technology, \\ Ghent University, 9000 Ghent, Belgium; Jo.Dewulf@ugent.be \\ * Correspondence: astrid.buchmayr@ugent.be; Tel.: +32-4-94-47-50-63
}

check for updates

Citation: Buchmayr, A.; Van Ootegem, L.; Dewulf, J.; Verhofstadt, E. Understanding Attitudes towards Renewable Energy Technologies and the Effect of Local Experiences. Energies 2021, 14, 7596. https:// doi.org/10.3390/en14227596

Academic Editor: David Borge-Diez

Received: 13 September 2021 Accepted: 11 November 2021 Published: 13 November 2021

Publisher's Note: MDPI stays neutral with regard to jurisdictional claims in published maps and institutional affiliations.

Copyright: (c) 2021 by the authors. Licensee MDPI, Basel, Switzerland. This article is an open access article distributed under the terms and conditions of the Creative Commons Attribution (CC BY) license (https:// creativecommons.org/licenses/by/ $4.0 /)$.

\begin{abstract}
For the planning of the energy transition, decision-makers need to be aware of the public attitudes towards renewable energy technologies (RETs) and the impacts of such energy facilities from a population's perspective. To facilitate the comparison of RET attitudes, a uniform survey design was used for four case studies (onshore wind, offshore wind, waste-to-energy, and biomass power) situated in the region of Flanders, Belgium. The survey analysis showed differences between the energy facilities with regard to the perceived impact on population health (combustion facilities were perceived more negatively) and landscape impact (wind energy facilities were perceived more negatively). All groups recognized the contribution of the RET facility to the economic development of the region. The effect of such local experiences on the overall evaluation of energy technologies was investigated using ordinal regression models. Personal experiences were found to be more meaningful predictors than socio-economic population characteristics or the proximity to the energy facility. In all investigated energy neighborhoods, the personal relationship of the participants to the landscape was a significant predictor of technology attitude. This points to the importance of investigating place attachment rather than pure visibility to understand the acceptability of land use for energy provision.
\end{abstract}

Keywords: renewable energy technology; public attitude; technology acceptance; experienced impacts; social sustainability; energy transition

\section{Introduction}

The issue of climate change dominates the discussion about the future development of the energy sector. While maintaining the same level and quality of energy supply, the mix of primary energy sources for the provision of energy has to undergo rapid changes to support the transition to a low-carbon economy as proposed by the European Green Deal [1]. With the transition to low-carbon energy sources, the type of technologies to generate energy and-most tangible for the population-the locations of energy generation will undergo structural changes. Decentralized energy generation and the connected infrastructure give rise to potential conflicts due to changing land use [2,3] and associated emissions [4]. At the same time, it presents a development opportunity for the regional economy and contributes to long-term job creation $[5,6]$.

The acceptance of the local population is a considerable condition for the realization of energy projects and thereby for meeting energy policy goals. Energy transition scenarios with a high degree of non-acceptance of new technologies by the population can significantly halt the reaching of carbon-neutral energy systems and increase energy import dependencies [7]. Resistance from the population repeatedly led to considerable delays and the need to re-plan projects [8-10]. To judge the sustainability of the energy transition, the effects (both negative and positive) on the local community need to be assessed and treated as valid concerns, just as the environmental impacts or economic feasibility of projects [11]. 
For this reason, this paper investigates attitudes and experienced impacts in different energy neighborhoods-that are communities located close to an energy generation plant. The aim is to provide a comparison of experienced impacts for the neighboring population of several renewable energy projects. As the methods for the assessment of impacts and experiences vary from study to study, the comparison of different projects is challenging, even more so for a comparison of projects of different technologies.

Previous research provides a range of different predictors for public attitudes. It is important to differentiate between the attitude towards a technology which can be determined by e.g., the general environmental attitude [12,13], social norms of the community [14], or personal norms [15], and the attitude towards a specific project. A positive attitude towards the technology does not automatically translate to a positive opinion of a specific energy project [16-18]. On the contrary, although support for the energy transition is strong, the range of possible conflict areas for energy projects is diverse and depends on the attributes of the project, e.g., visual impacts were found to be highly relevant for wind energy projects [19-21] but might not be relevant for other technologies. The issue of aesthetics and visual impacts is also present in the discussion regarding solar farms [14,22] and hydropower plants [23]. Still, a comparison of visual impacts of renewable energy technologies (RETs) is challenging due to the differences in fundamental design and plant size, e.g., for micro-hydropower, the impact as well as potential benefits for the local population are perceived rather differently than for large dam projects [24]. Devine-Wright [25] stressed the importance of the personal connection to a location and advocated to investigate place attachment, which results in an emotional response to changing landscapes, rather than observable physical landscape changes. For the case of biomass energy, the literature shows that opposition can be based on public mistrust [26] which is also sometimes an issue for wind energy [27]. Another study pointed at the olfactory impact as determinant of acceptance of biomass power plants [4]. Moreover, public opposition against renewable energy can be based on the concern about possible negative impacts on the immediate environment and wildlife [28]. A common misconception is that opposition is based on the proximity of energy plants, although modern research repeatedly refutes that [29,30]. On the contrary, studies showed that familiarization with concrete projects leads to a higher degree of support for projects of the same type [31,32].

On the other hand, the public is also aware of the positive contributions of energy projects to the economy and local employment $[33,34]$. For example, a study found for the case of Belgium that the transition to a green economy creates additional employment opportunities for young people entering the job market [6].

Negative attitudes towards energy projects are often misclassified as not in my backyard (NIMBY) behavior when projects are opposed by the local population presumably due to selfishness [29]. The use of the NIMBY term to explain attitudes is problematic, but it is still a prevalent strategy to frame public opposition as an unjustified reaction [35]. Researchers argue for the abandonment of such misleading language altogether and instead focus on the mechanisms behind low community acceptance, land use disputes, and public participation strategies for siting decisions [29,36].

As the range of conflict areas varies, the assessment methods for different projects are also quite heterogeneous. For example, the landscape impact and the population's perception regarding the new land use is commonly discussed, especially for wind energy, but there is no consensus on how such impacts should be assessed and how the perception of the public regarding the caused disamenity can be quantified. Assessment frameworks to quantify the land use impact include Hedonic pricing [37], the use of photo simulations to simulate aesthetic impacts [38], or GIS simulations [39] providing quite different results.

As a uniform assessment method for the impact on the life quality and landscape is missing, this study aims at introducing a standardized survey design in order to provide comparable results for different energy projects.

The literature provides snapshots of energy technology attitudes and societal impact on the basis of selected case studies. There are only a few examples of studies that focus 
on comparing attitudes of different energy technologies. Truelove [40] investigated public perception of energy technologies and highlighted the role of emotional reactions towards coal, natural gas, nuclear, and wind energy in a US-based consumer survey. She found wind energy to be the most favored energy technology. Firestone and Kirk [41] pointed out that technology acceptance is better explained by comparing different project alternatives than by focusing on the opposition against a specific project. They found that the majority of respondents in a US-based study preferred living close to a wind park rather than a centralized plant using other energy sources such as nuclear, coal, natural gas, or solar. As RETs play a crucial part in the energy transition, such comparison studies should be extended to cover different types of RETs more prominently than conventional energy technologies. Ribeiro et al. [42] found for the case of RETs in Portugal that solar and wind energy were less subject to negative attitudes than other investigated RETs. They included the population's perception of economic, environmental, and social impacts as predictors for the attitude but did not include landscape perceptions, which reportedly plays an important role in whether technology projects are accepted or not [4]. Although the abovementioned studies [40-42] all offer comparisons between different energy technologies, they use fundamentally different survey designs and models explaining technology acceptance and attitudes.

This paper offers a comparison between different technology types by using a uniform survey design in a number of case study surveys. Four cases are compared: onshore wind, offshore wind, waste-to-energy, and biomass power. The investigated cases are representative of renewable energy technologies according to the terminology used by EU organizations (for energy from waste incineration under the condition that industrial and municipal waste of biological origin is used) [43]. However, the renewability of energy inputs in the case studies, in particular the renewability of biomass and waste fuels, was not verified in this study.

The case studies were all located in the region of Flanders, Belgium. A uniform questionnaire was used to survey the population in different energy neighborhoods in order to facilitate the comparison of positive and negative impacts and experiences for different types of energy projects. The study thereby goes beyond the typical investigation of a specific energy technology and addresses the gap regarding the comparability of experienced impacts of RETs. As distance and line of sight play a role in the perception of impacts, samples were further subdivided to control for the influence of proximity to the investigated energy facilities.

Furthermore, it was investigated how these experiences actually impact the expressed general attitude towards the neighboring technology, using ordered logistic regression analysis. The aim was to investigate the influence of different potential determinants of the general attitude towards the neighboring energy technology, namely socio-economic characteristics, environmental attitude, knowledge about the electricity sector, proximity to and experienced impact of the surveyed energy plant. A better understanding of the formation of technology attitudes and the significance of personal experiences are decisive for the sustainable design of energy transition pathways without compromising the quality of life for the local population in the energy neighborhoods.

\section{Materials and Methods}

This paper presents the results of population surveys conducted in four different energy neighborhoods-which are residential areas close to energy-generation facilities-for the case of the Flanders region in Belgium. The energy and climate action plan 2021-2030 of the Flemish government defines the planned contributions of the Flemish energy sector to reaching the national goal of a 35\% reduction in greenhouse gas emissions by 2030 [44]. Moreover, the nuclear phase-out planned for 2025 will leave a gap in the electricity generation capacity of Belgium. An increase in renewable energy capacities is required to ensure the domestic supply of low-carbon electricity. In order to contribute insights for the drafting 
and implementation of energy transition policies for the Flemish region, it is important to investigate the varying perceptions of the population regarding different RETs.

To provide this comparison of population perceptions in Flanders, four energy neighborhoods were investigated. The case studies included two wind energy neighborhoods, one located close to an onshore wind park, and one located at the coast close to an offshore wind park ( $n=200$ for each case). Moreover, samples were collected in the neighborhoods of a waste-to-energy facility $(n=161)$ and of a power plant using biomass fuel $(n=210)$. The four case study surveys were conducted during the time span of August 2019 to October 2020, with data collection of each specific survey taking 6 to 16 weeks. Each of the case study groups was asked for the assessment of the specific situation regarding the neighboring energy technology and the related attitudes: for example, the onshore wind group stated the experienced impact only for the case of wind energy in their neighborhood.

In order to control for differences in perceptions due to proximity and according to the magnitude of exposure to energy facilities, data were collected in two sub-samples for each case study group. One sub-sample group consisted of people living in close proximity to the energy facility, while the other group included participants still living in the energy neighborhoods but at greater distance. The characteristics of Group Close Proximity and Group Neighborhood are described in Table 1.

Table 1. Sample characteristics for the four case study groups.

\begin{tabular}{|c|c|c|c|c|c|}
\hline Dataset & Collection Date & Location & $\begin{array}{l}\text { Close Proximity } \\
\text { Sample }\end{array}$ & $\begin{array}{l}\text { Neighborhood } \\
\text { Sample }\end{array}$ & Survey Method \\
\hline Onshore wind & January-April 2020 & Eeklo & $\begin{array}{l}\text { In line of sight of } \\
\text { wind park } \\
n=109\end{array}$ & $\begin{array}{l}\text { Same area without line } \\
\text { of sight } \\
n=91\end{array}$ & $\begin{array}{l}\text { Face-to-face interviews at } \\
\text { survey locations and } \\
\text { distribution of online } \\
\text { questionnaires for which } \\
\text { responses were filtered to retain } \\
\text { only responses from the } \\
\text { municipalities Eeklo, } \\
\text { Maldegem, and Kaprijke }\end{array}$ \\
\hline Offshore wind & $\begin{array}{c}\text { August-September } \\
2019\end{array}$ & Oostende & $\begin{array}{l}\text { At the coast in line of } \\
\text { sight of wind parks } \\
\qquad n=100\end{array}$ & $\begin{array}{l}\text { Same area without line } \\
\text { of sight } \\
n=100\end{array}$ & $\begin{array}{l}\text { Face-to-face interviews at } \\
\text { survey locations }\end{array}$ \\
\hline Waste-to-energy & June-July 2020 & Oostende & $\begin{array}{l}\text { Within of } 2.5 \mathrm{~km} \\
\text { radius of power plant } \\
n=73\end{array}$ & $\begin{array}{l}\text { Neighboring } \\
\text { municipalities within } \\
\text { radius of } 10 \mathrm{~km} \\
n=88\end{array}$ & $\begin{array}{l}\text { Face-to-face interviews in the } \\
\text { area in close proximity to the } \\
\text { plant and online questionnaires } \\
\text { for the neighborhood sample } \\
\text { for which responses were } \\
\text { filtered to retain only responses } \\
\text { from the municipalities within a } \\
10 \mathrm{~km} \text { radius }\end{array}$ \\
\hline Biomass & $\begin{array}{c}\text { September-October } \\
2020\end{array}$ & $\begin{array}{l}\text { Rodenhuize/ } \\
\text { Herdersbrug }\end{array}$ & $\begin{array}{c}\text { Within } 6 \mathrm{~km} \text { radius } \\
\text { of power plant } \\
n=105\end{array}$ & $\begin{array}{l}\text { Neighboring } \\
\text { municipality without } \\
\text { power plant } 30 \text { to } \\
40 \mathrm{~km} \text { distance } \\
n=105\end{array}$ & $\begin{array}{l}\text { Distribution of letters in targets } \\
\text { areas with invitation to } \\
\text { participation in online } \\
\text { questionnaire }\end{array}$ \\
\hline
\end{tabular}

For both wind energy cases, the Close Proximity group was moreover characterized through the visibility of wind turbines from the participants property. This distinction was not possible for the waste-to-energy and biomass plant as the facilities were not isolated structures and not visible over large distances. For these, the sample was collected in the closest residential areas to the facility. The difference between Group Close Proximity and Group Neighborhood is thereby the level of exposure to the investigated power plant. This includes exposure to visible impacts in the wind energy groups and exposure to the proximity-related impacts, such as emissions, for all groups.

Due to the COVID-19 pandemic and the corresponding governmental regulation to observe social distancing, the survey method changed from primarily face-to-face interviews to the use of online questionnaires which could be distributed both by letter invitation and 
social media groups. Table 1 provides a summary of the sample characteristics for the four case study groups.

The energy case studies were chosen to represent the technologies with high significance for the Flemish energy transition. The technologies are summarized as renewable energy technologies as this is also the label used in Flemish policy documents [44], although in the communication of policy goals, the definition of true renewability of fuels is lacking. Therefore, in the population surveys, it was abstained from classifying the investigated technologies as "renewable" in order to avoid unsubstantiated associations about the renewability of energy provision.

Wind energy, both onshore and offshore, is a key element for the Flemish energy transition [44]. Moreover, the technology is often met with public opposition, which requires specific attention and potentially delays the implementation process. Therefore, surveys were conducted both for onshore and offshore wind cases to provide a comparison of how the different location of application is perceived by the population. The offshore wind case study was conducted at the coast of the Belgian Part of the North Sea, where within a $30 \mathrm{~km}$ distance, wind turbines can be seen from the shore, clear weather provided. The location chosen for the onshore wind case study was the community living in the vicinity of one of the first Flemish wind parks. The location stands out through the existence of public participation schemes which accompanied the different expansion stages of the local find parks. The sample thereby included a large share of participants who were part of an energy cooperative, i.e., being co-owners or investors of the wind parks at the investigated location. As in reality only a small share (10\%) of households at the survey location are part of an energy cooperative, the sample was corrected using post-stratification weights in order to avoid the concentration of an overly environmental-positive attitude.

The Flemish Energy and Climate plan moreover foresees the expansion of district heating systems using renewable heat sources. More than half of the heat from renewable sources should be provided by bio-energy sources (solid biomass, biogas, and waste incineration). While municipal waste generation is predicted to reduce until 2030 due to waste reduction measures, waste incineration will still play an important role both for energy provision as well as for waste management. The waste-to-energy case study took place at the location of a plant with the capacity to incinerate 180,000 tons of waste per year, which is, compared to other waste-to-energy plants in the Flemish region, a large installation. Moderate growth is also needed in the biomass sector, but currently no new facilities are planned. However existing plants will stay part of the energy landscape. The biomass plant used for the case study is a former coal power plant that was adapted in 2011 for the use of wood pellets with a total capacity of $180 \mathrm{MW}$. As it is situated in an industrial area, the target area for the sample in close proximity was expanded to the next residential areas. The neighborhood sample was taken in the next municipality where there is no power plant present.

In order to compensate for the drawbacks of the used nonprobability sampling method, post-stratification weights were used on the samples to adjust the demographics of the respective group to the actual characteristics of the population in Flanders. Adjustments were made to gender, age, and education distribution. Moreover, the aim was to achieve a 50:50 share between the Close Proximity and the Neighborhood group in all samples. Only for the onshore wind case, an additional weight was applied to correct for the high number of energy cooperative members in the sample and thereby avoid a concentration of overly positive attitudes due to the personal engagement with the wind energy topic. To find the post-stratification weights, an iterative proportional fitting algorithm, the rake-function implemented by Lumley [45] in the R survey $v 4$ package was used.

The four case study groups were analyzed using $R$ version 3.6.3 [46]. As affective experiences play a major role in the formation of attitudes $[47,48]$, the survey design focused on the assessment of different experiences in the energy neighborhoods. The used questionnaire was structured in five main question blocks covering (1) the willingness to adapt one's lifestyle in the course of the energy transition, (2) knowledge about the 
electricity mix, (3) personal evaluation of the energy technology's impact on life quality and on the economy in the energy neighborhood, (4) personal evaluation of the energy technology's impact on landscape quality in the energy neighborhood, and (5) general attitude towards the neighboring RET used the energy neighborhood. It is important to point out that the technology-specific impact and characteristics (points 3, 4, and 5) were answered by each group only for the technology in their neighborhood: for example, the onshore wind group stated the experienced impact only for the case of wind energy in their neighborhood. The points 1 and 2 were not technology-specific.

The general attitude towards the neighboring energy technology was measured on an ordinal scale from 1 (disadvantageous technology) to 5 (advantageous technology). This attitude variable was analyzed for each case study in detail using ordinal regression models. The objective for the regression models was to identify the influence of personal experience for the different RETs in contrast with other population characteristics.

To reduce the number of determining variables and avoid overlaps, questionnaire items were summarized to subcategory factors. The factors were estimated using the regression method according to Thurstone [49], with weighting factors based on covariance and factor loadings of the variables which were to be aggregated. Table 2 provides an overview of which questionnaire items were aggregated into the respective factor scores.

Table 2. Overview of questionnaire items and respective factor variables.

\begin{tabular}{|c|c|}
\hline Questionnaire Items Categories & Independent Variables in Regression Model \\
\hline \multicolumn{2}{|l|}{ General descriptions } \\
\hline Socio-economic characteristics & Gender, age, education level, neighborhood characteristics, home ownership \\
\hline Proximity to surveyed power plant & Proximity to surveyed power plant \\
\hline \multicolumn{2}{|l|}{ Willingness to adapt to energy transition } \\
\hline Willing to change lifestyle for green energy future & \multirow{2}{*}{ Willingness to adapt } \\
\hline Willing to pay more for green energy & \\
\hline \multicolumn{2}{|l|}{ Knowledge about the electricity mix } \\
\hline Evaluation of current electricity mix by share of energy carrier & Knowledge about electricity production in Belgium \\
\hline \multicolumn{2}{|l|}{ Personal evaluation of the impact on life quality and economy } \\
\hline Contribution to local economy & \multirow{2}{*}{ Development of local economy } \\
\hline Local job creation & \\
\hline House prices & Development of house prices \\
\hline Population health and safety & Population health and safety \\
\hline Disturbance due to noise & \multirow{3}{*}{ Impact on living environment } \\
\hline Disturbance due to smell & \\
\hline Disturbance due to increased traffic & \\
\hline \multicolumn{2}{|l|}{ Personal evaluation of landscape impact } \\
\hline \multicolumn{2}{|l|}{ Reduces the feeling of attachment to the landscape } \\
\hline Does symbolize a future-oriented development & \multirow[t]{2}{*}{ Impact on landscape attachment } \\
\hline Is part of the landscape identity of the region & \\
\hline \multicolumn{2}{|l|}{ Adds to the unique character of landscape } \\
\hline Adds an artificial quality to the landscape & \multirow[t]{2}{*}{ Impact on landscape aesthetics } \\
\hline Causes that untouched nature is lost & \\
\hline Provides possibilities for recreational activities & \multirow{3}{*}{ Impact on recreational value of landscape } \\
\hline Prevents free time activities in the vicinity & \\
\hline Impacts ability to relax & \\
\hline
\end{tabular}

The descriptive results for the determining variables are presented in Sections 3.1-3.4 and provide an overview of how impacts vary between the different RETs. The general 
attitude towards the different energy types was analyzed using ordinal regression models and presented in Section 3.5. For this, a proportional odds logistic regression model [50] was used. The underlying assumption of this model is that logit coefficients $\beta$ are the same (i.e., parallel lines) across the levels of the ordinal dependent variable. If this assumption does not hold, alternative models need to be considered [51]. In the analysis at hand, the proportional odds assumption was tested according to the procedure of Brant [52] using Wald tests for evaluating the differences of $\beta$ s across different levels of the dependent variable. The test provided an overall estimation for the complete model and separately for each of the independent variables. An alternative to the proportional odds model is a partial proportional odds model where the assumption is relaxed for a subset of variables. This is done also for the presented case studies where the Brant test showed that a fully proportional model was not suitable.

\section{Results and Discussion}

The result section presents the participant's willingness to adapt, knowledge, and personal evaluations of impacts using descriptive statistics (Sections 3.1-3.4). The last sub-section (Section 3.5) includes the description of the general attitude towards the neighboring energy technology and the ordinal regression models that are used to determine explanatory factors of the general attitude towards the different RETs.

\subsection{Willingness to Adapt One's Lifestyle and Attitude towards Renewable Energy}

The four samples were analyzed regarding the self-assessed attitude towards renewable energy. Based on the approach used by Bertsch et al. [4], participants were asked about their willingness to change their own lifestyle and their willingness to pay (more) to achieve an environmentally friendly society.

First, the willingness to adapt due to the energy transition is displayed in Figure 1. The majority of participants in all groups agreed or strongly agreed that they are willing to change their lifestyle in order to support the energy transition. On the other hand, the willingness to pay more for energy was lower in all groups with only $24 \%$ (case waste-toenergy) to $38 \%$ (case offshore wind) stating to be willing to pay more. In comparison, the two wind energy groups displayed higher willingness to change and to pay than the other two groups.

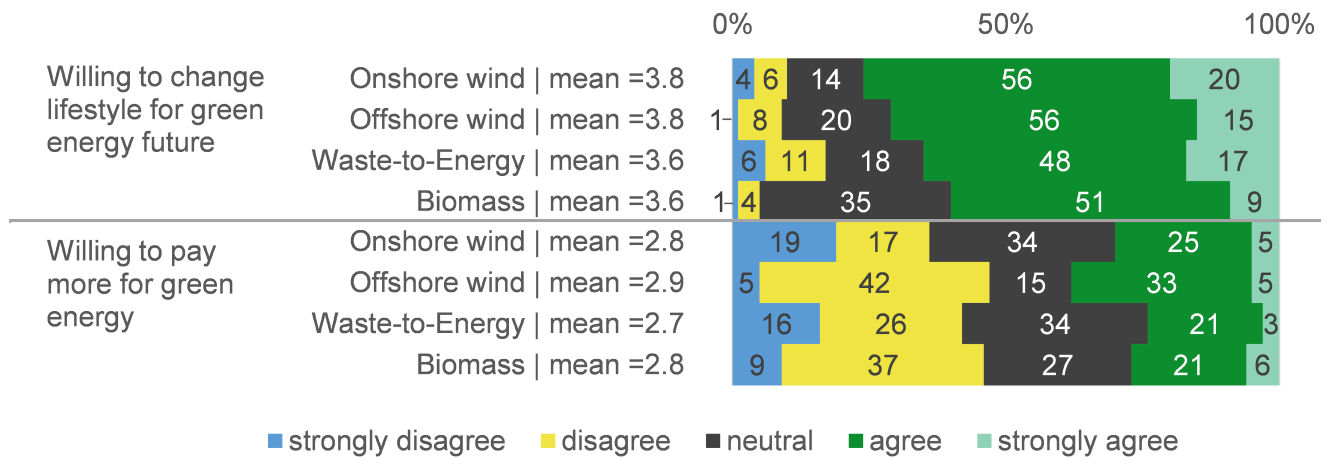

Figure 1. Distribution of participants willing to change and to pay in \% per survey group. For the calculation of the mean value, a scale from 1: very negative to 5: very positive was used.

Kruskal-Wallis $\mathrm{H}$ tests showed that there is a significant difference for the willingness to change $\left(\chi^{2}(3)=25.043, p<0.001\right)$ and willingness to pay $\left(\chi^{2}(3)=13.142, p=0.004\right)$ between the four groups. The underlying reasons for these location-specific differences would require further research beyond the scope of the existing surveys.

As the samples were adjusted to be comparable in terms of socio-economic characteristics, the differences in attitude towards renewable energy cannot be attributed to the different composition of the groups. However, a possible reason for the different levels of willingness to adapt could be found in the environment of the sample groups. While the 
survey for the wind energy groups took place in a more urban environment, the waste-toenergy group was located in a more suburban environment, and the biomass plant was located close to a rural community. The urgency of climate change mitigation could be experienced differently in different residential environments. Moreover, the financial status and capabilities of the sample population were not assessed in this study. This additional information might have offered an indication if participants realistically have the possibility to adapt their lifestyle for the energy transition, as willingness to pay more is determined by household income $[53,54]$.

\subsection{Knowledge of the Population about the Electricity Generation Mix}

The knowledge of the population regarding relevant energy carriers in the Belgian electricity mix was evaluated by asking participants to estimate the share of energy carriers in the total electricity mix in predefined percentage ranges. Participants had to assign these percentages to five energy sources (wind, solar, fossil, nuclear, and imports) that currently represent the main shares in the Belgian electricity mix. If the participants assigned the share of the energy carrier to the correct range category, this was counted with 1 point. Incorrect answers were recorded with 0 points. Using this system, a knowledge score per participant was calculated, ranging from 0 to the maximum of 5 points. Figure 2 provides an overview of how participants in the different groups scored on this scale.

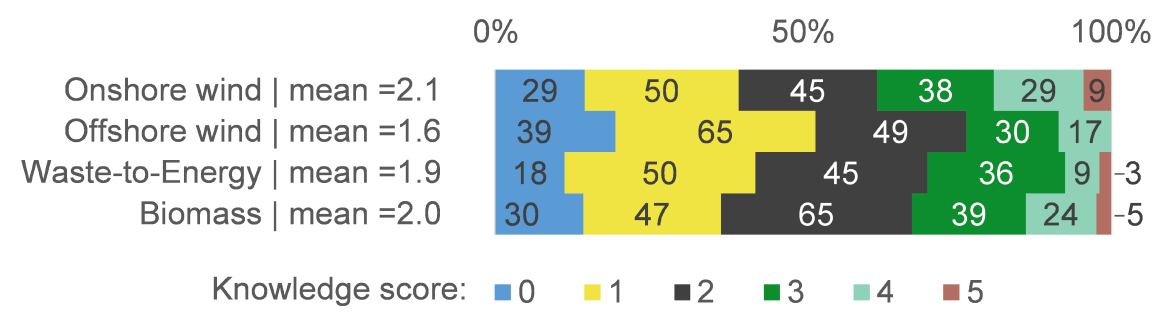

Figure 2. Knowledge score based on the number of correct estimations regarding the share of different energy carriers in the Belgian electricity mix of participants. Distribution among the participants in \% per survey group.

The majority in each group scored below 2 points, which is a low to medium score. The offshore wind group showed generally a lower knowledge score (1.6) than the other groups. The four groups showed significantly different distribution of knowledge scores (KruskalWallis $\mathrm{H}$ test: $\left.\chi^{2}(3)=13.39, p=0.004\right)$. The analysis highlighted that men displayed on average a higher knowledge level than women in all groups. Using Spearman's rank correlation, the relationship between the knowledge score and the formal education level was analyzed, but no significant correlation was found (onshore wind: $r(198)=-0.06$, $p=0.421$; offshore wind: $r(198)=0.13, p=0.07$; waste-to-energy: $r(159)=-0.04$. $p=0.614$; biomass: $r(208)=0.07, p=0.285)$. The difference in knowledge levels between the offshore wind and the other groups cannot be attributed to socio-economic differences of the survey groups, as the samples were all equally stratified to match the distribution of socio-economic groups in the Flemish population.

\subsection{Personal Evaluation of Impacts on Life Quality and Local Economy}

Each group represents an independent case study of the respective technology. Thereby, each group evaluated the experienced impact of the neighboring energy technology on their surroundings and well-being. Participants were asked to evaluate different dimensions of well-being, i.e., economic and job development, development of house prices, as well as health impacts. Moreover, the disturbance levels of noise, smell, and traffic in the neighborhood were measured.

Figure 3 shows that the impact of energy technologies on the economic development and job creation was evaluated positively. While $43 \%$ of the onshore wind group evaluated the contribution of the nearby wind park to the local economy as positive or very positive, 
only $28 \%$ saw a positive impact on local job creation. This is quite different from the other groups in which a majority stated that there is a positive effect on local jobs. The most positive response was observed in the waste-to-energy group. Studies showed that the employment effect proved to be a strong argument for the local population to support or accept renewable energy development $[55,56]$, even though other local impacts such as health or landscape were often weighted higher [4].

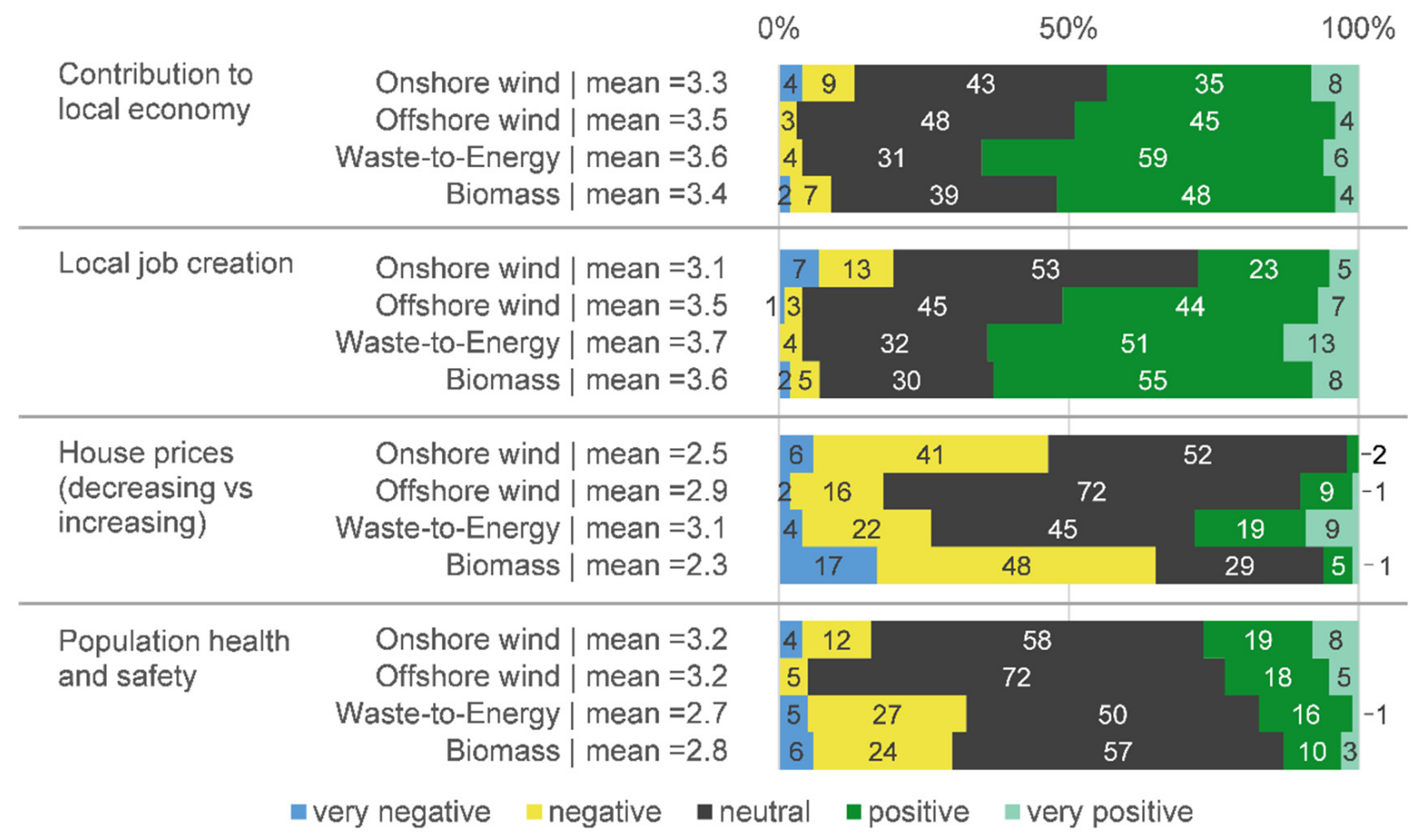

Figure 3. Experienced impact on the local economy and health in the energy neighborhoods in \% per survey group. For the calculation of the mean value, a scale from 1: very negative to 5: very positive was used.

While the valuation of economic development and jobs was positive in the waste-toenergy group, it was the only group where the evaluation of house prices leaned more towards an observed increase. Different studies covered the negative impact of wind energy development on house prices $[57,58]$, but evidence for other renewable energy types is missing.

For the evaluation of health impact, a divide between the groups was observed. The wind energy group evaluated the impact on health as positive, while the other groups (located in the neighborhoods of waste-to-energy and biomass plants) saw a negative impact of these combustion technologies. As a certain amount of emissions is associated with these combustion technologies, the result is not surprising. The mean values of 2.7 for waste-to-energy and 2.8 for biomass energy present only a small deviation from a neutral evaluation and in both cases the majority of participants assigned the power plants a neutral impact on health and safety of the neighborhood.

The comparison further shows that biomass power was experienced to have a negative effect on the residential area by causing disturbing noise, smell, and increased traffic; see Figure 4. More than half of the participants in the biomass group rated the disturbance due to smell and due to increased traffic as negative or very negative. Moreover, $40 \%$ report annoyance due to noise. That is more than in the onshore wind group, where such problems could also be expected. Although the activities of the biomass and waste-toenergy plants are rather similar, the impact of the biomass plant was negatively evaluated by a significantly higher share of participants. 


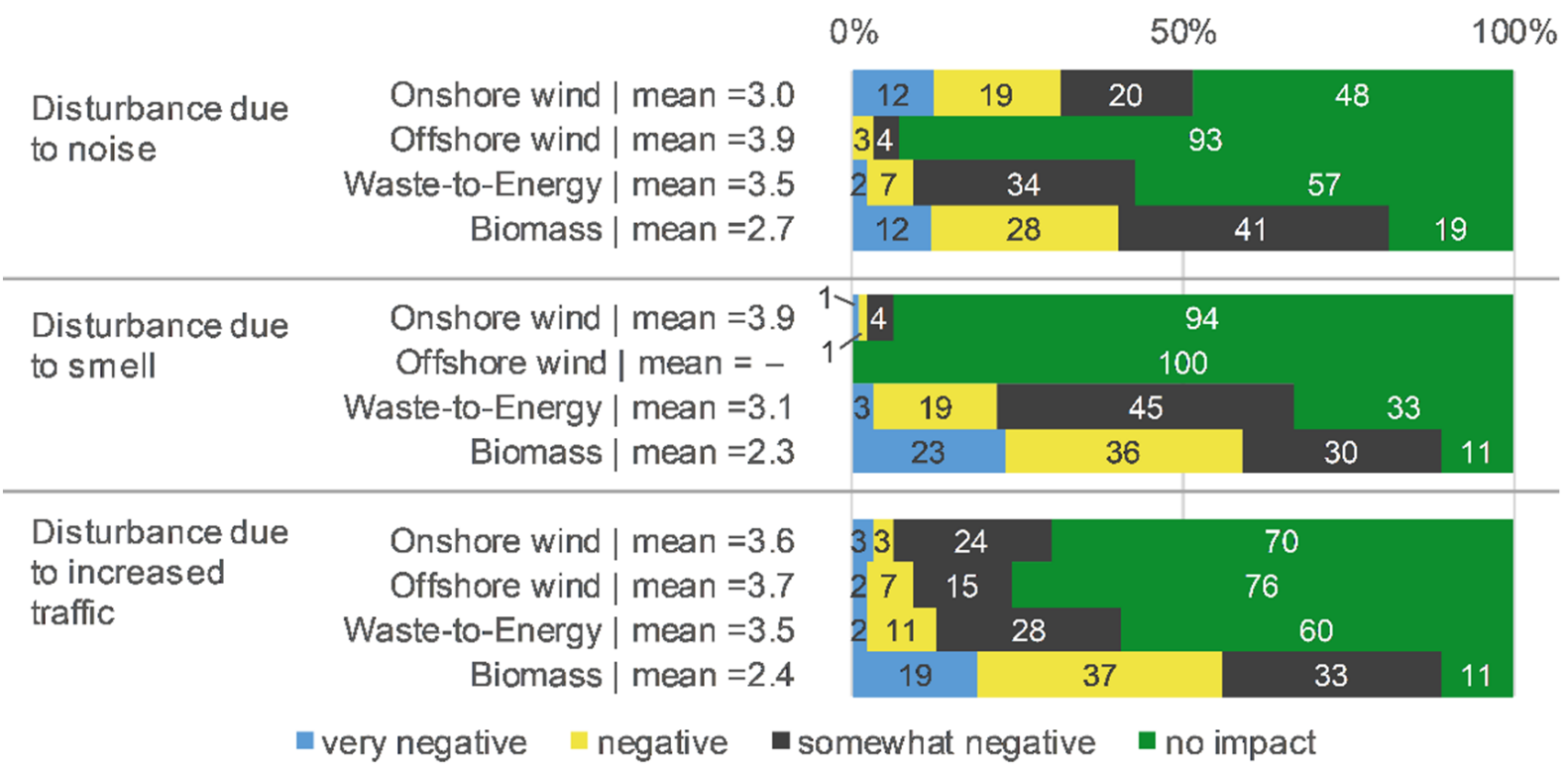

Figure 4. Experienced level of disturbance in the energy neighborhoods in \% per survey group. For the calculation of the mean value, a scale from 1: very negative to 4 : no impact was used.

In the case of waste-to-energy and biomass plants, the impacts were experienced differently depending on the level of exposure to the power plants, which was analyzed by the comparison of the two sample groups located at different distance to the plant. For the waste-to-energy case, the health impact was experienced more negatively in the group living close to the power plant than the one further away. This shows that the population living close to the energy facility is more likely to see the facility as source of health risks. Such a relationship between proximity and higher perceived risks is confirmed in the literature for a number of technologies [32,59], including for waste-to-energy facilities [60]. Moreover, the annoyance due to smell and due to increased traffic was actually perceived as less negative in the group living in Close Proximity than in the Neighborhood group. This would need further investigation along the traffic routes of waste trucks. There is the possibility that the results point at the general notion that waste collection trucks are to a certain degree disturbing. Finally, job creation was experienced more positively in the Close Proximity group, pointing at the possibility that people more familiar with the operation of the plant, due to proximity, experience the day-to-day operation of the plant as labor-intensive.

Similar differences were observed for the biomass power plant: health impacts and annoyance due to smell were experienced more negatively in the group living in close proximity. Job creation, on the other hand, was experienced more positively by people living further away from the plant. The detailed frequency tables can be found in Tables A1 and A2 in Appendix A.

The different perceptions of health and disturbance levels between the sub-groups for the waste-to-energy and the biomass plants can be attributed to observable emissions due to fuel storage, handling, and combustion. Although certain project attributes are experienced more severely in close proximity of the power plant, a similar trend could not be observed for the evaluation of the general attitude towards the technology; see Section 3.5.

\subsection{Personal Evaluation of Landscape Impacts}

Figure 5 shows the population's evaluation of different aspects of landscape impact. Each group evaluated the impact of the respective neighboring energy technology on the landscape of their own neighborhood. Landscape aspects were measured based on the concept of Cultural Ecosystem Services. According to the classification framework of ecosystem services CICES, landscape can offer the population the cultural services of 
recreation, aesthetics experiences and the feeling of personal attachment [61]. Participants were asked for the impact of the energy facility on these cultural aspects of the landscape.

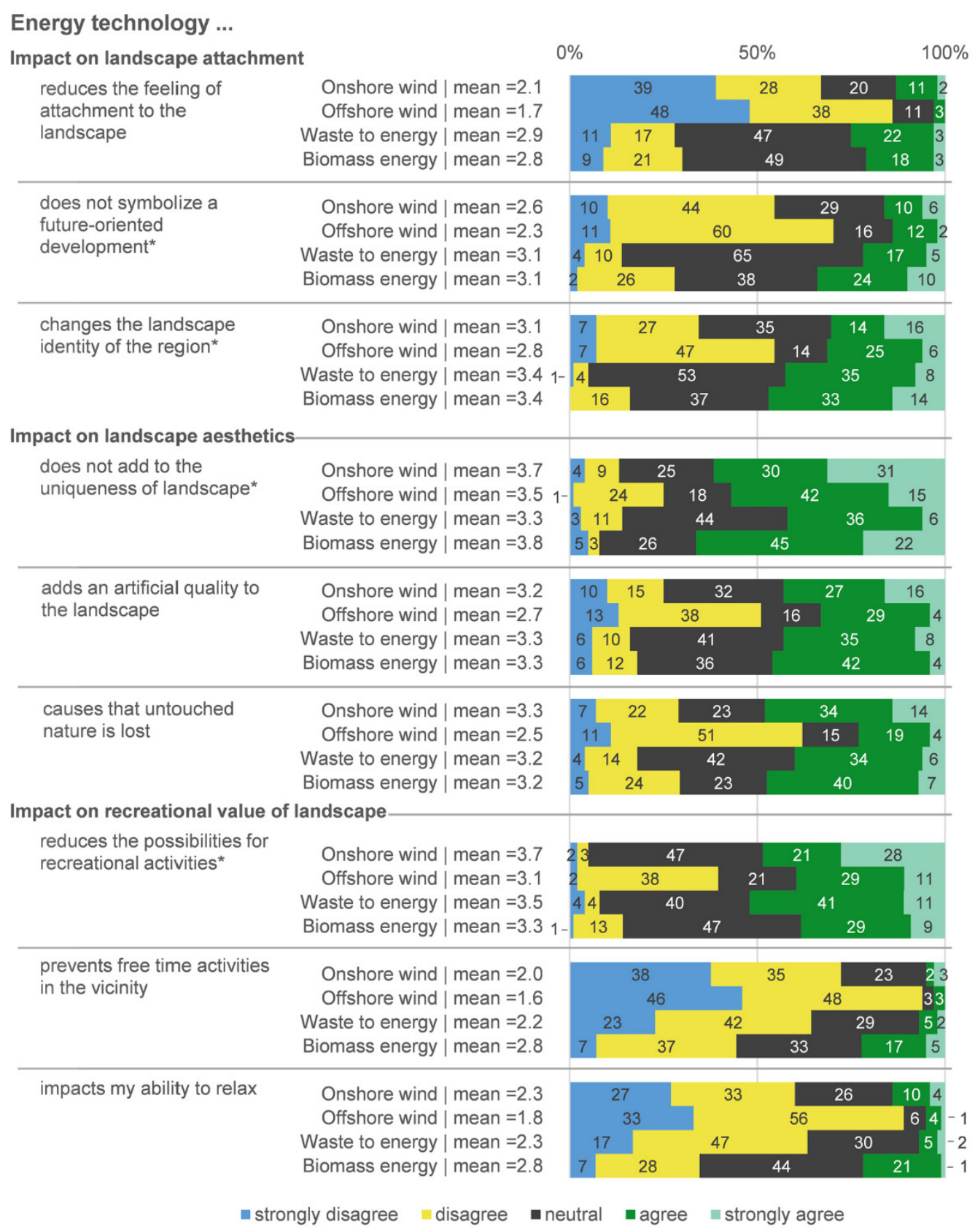

* statement was formulated positively in the survey and recoded for the presentation in this figure

Figure 5. Experienced impact on landscape quality in the energy neighborhoods in \% per survey group. For the calculation of the mean value, a scale from 1: strongly disagree to 5: strongly agree was used.

In general, the participants in all groups reported no strong impacts of the energy plants on their ability to relax or spend their free time in the area. This can be seen when examining the presented mean values but also when analyzing the results in detail. Mostly only a single-digit percentage of participants reported a negative impact on free time and relaxation-the biomass group with $22 \%$ being an exception. While the power plants did not present a barrier for recreation, only few participants in any of the groups reported a positive impact of the plants by contributing to more recreational possibilities in the region. 
The largest negative impact was reported in the category of aesthetic value. About $40 \%$ of participants in the onshore wind, biomass, and energy-to-waste groups experienced that the energy plant both adds artificiality to the landscape and disturbs the feeling of being in untouched nature. In the case of the offshore wind group, these categories were evaluated as considerably less intrusive, which is not surprising as there is a large distance between the wind parks and the shore. The majority of the offshore wind group even stated that the wind parks are part of the identity of the region, where all other groups saw negative impacts on the regional identity because of the energy plants. Already a previous study confirmed that wind parks at the Belgian coast are well accepted by the local population and tourists [62]. The current study provides the additional insight that energy generation at the site is even considered a part of the regional identity.

With regard to the personal connection to landscape, the waste-to-energy and the biomass groups saw a stronger impact on the landscape than the wind groups. Moreover, only 13\% (onshore) and 3\% (offshore) of the wind groups stated that the respective power plants reduce the population's attachment to the landscape. This is a surprising low percentage as research suggests that landscape attachment is the basis for frequent opposition to wind energy [63]. On the other hand, the contribution of energy landscapes to a greater societal purpose, such as carbon-neutrality, can be considered as an additional environmental service and contribute to acceptance of land use changes by the population [64]. In the case of the other groups, the negative impact on the feeling of attachment was more pronounced, although still rather low with 21\% (biomass) and 25\% (waste-to-energy) of participants seeing a negative impact.

As the surveyed RETs were located in distinctly different landscapes and also presented different types of visual intrusion, the differences between the evaluations were not surprising. The literature extensively covers that the evaluation of landscapes depends on personal evaluations of attachment, aesthetics, and intended functions [3,65]. Such differences are also confirmed by Ioannidis and Koutsoyiannis [66], who stated that the severity of experienced landscape impact strongly depends on already existing landscape characteristics. Moreover, the value of the individual landscape for the population needs to be considered, rather than aesthetic characteristics such as visibility [67].

Whether the participants lived in line of sights of the wind parks (Close Proximity group) did not influence the overall evaluation of landscape impacts in both the onshore and offshore groups. However, the distance to the plant proved to have a significant effect on the evaluation of the waste-to-energy technology. Participants living close to the waste-to-energy plant reported a more negative impact on their feeling of attachment to landscape than people living further away. Interestingly, the recreational value of the landscape was found to be not negatively impacted. People living further away even evaluated the impact on recreational activities more negatively than people living close. This points to the possibility that the population in the direct vicinity becomes accustomed to the power plant and can still relax in their energy neighborhood. The majority of the participants, both close and further away, reported the impact to be rather low. The detailed frequency tables can be found in the Appendix A (Table A3).

\subsection{Explaining the Attitude towards Renewable Energy Technologies}

Finally, the general attitude towards the surveyed RETs is described, and influencing variables are identified using ordinal regression models. Each group was asked for the attitude towards the RET which was located in their neighborhood. The participant's general attitude towards the neighboring technology was measured based on the participant's evaluation of the technology on a 5-point scale from disadvantageous to advantageous. This measure allowed participants to incorporate existing knowledge and the personal perception of technology characteristics. Accordingly, assigning advantages was interpreted as positive attitude and disadvantages as negative attitude.

The observed attitude levels in the different groups were quite positive. As can be seen in Figure 6, the majority in the wind energy groups evaluated the technology favorably, 
with $65 \%$ in the onshore group having a positive attitude (more advantages) and even $81 \%$ in the offshore group. The attitude-although still overall neutral or positive-was less distinct in the waste-to-energy and the biomass case.

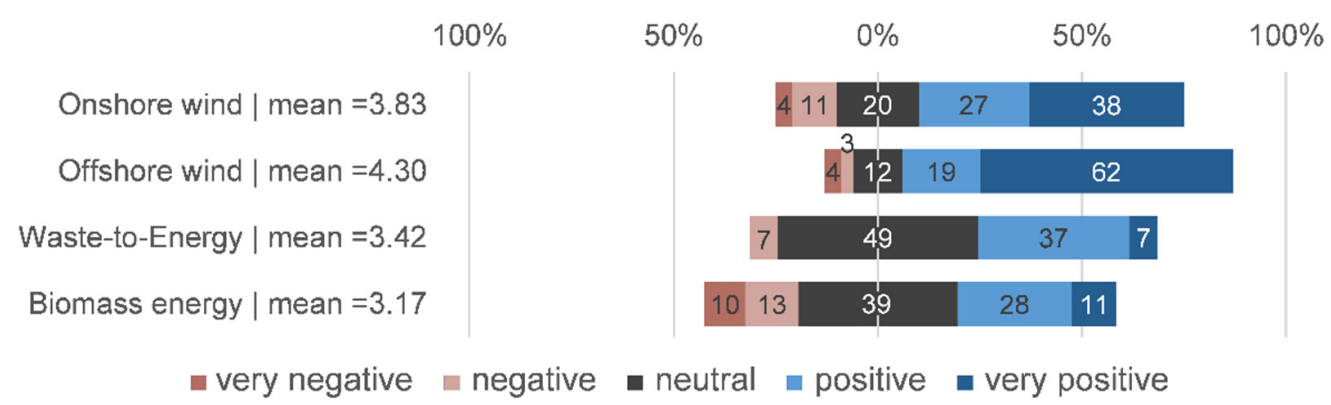

Figure 6. Attitude towards the neighboring technology in \% per survey group. Participants answered if they evaluate the neighboring technology as more advantageous or disadvantageous. For the calculation of the mean value, a scale from 1: very negative to 5: very positive was used.

To explain the people's attitudes for energy technologies, Bertsch et al. [68] used ordinal regression models. Ribeiro [42] used logistic ordinal regression to show the impacts of socio-economic, cultural, demographic, and location aspects on acceptance and NIMBYism. For near-shore wind parks, Johansen [69] found that second homeowners have a more negative attitude than permanent residents using a hierarchical regression model. In order to analyze the presented case studies, ordered logistic regression models were used to provide information on the potential determinants of the attitude towards the neighboring energy technology. All models included the same collection of independent variables describing socio-economic characteristics, environmental attitude, knowledge about the electricity sector, and proximity to and experienced impact of the surveyed energy plant. The effect of these variables on the dependent variable, i.e., attitude towards the neighboring technology, was investigated.

Proportional odds models as proposed by McCullagh [50] were fitted for each of the case studies. In the case of the onshore wind group, it was found that the proportional odds assumption did not hold for all the presented variables, which implies that the presented coefficients might be unreliable. To counter that, a partial proportional odds model was fitted with the proportional odds assumption relaxed for some variables. Table 3 shows the resulting regression model for each of the surveyed groups. The Nagelkerke Pseudo $\mathrm{R}^{2}$ values provided in the table specify the percentage of variance explained in the models. The values found for the models indicate that between 30 and $48 \%$ of variance can be explained depending on the different models. For the onshore wind case study, a partial proportional odds model was fitted where the proportional odds assumption was relaxed for the variables of education level and experienced impact on landscape attachment. The regression coefficients of these variables varied depending on the level of the ordinal dependent variable, although due to clarity, Table 3 only shows one coefficient. The full model description is included in Table A4 in the Appendix A. 
Table 3. Ordinal regression models to predict the general attitude towards the neighboring technology.

\begin{tabular}{|c|c|c|c|c|c|c|c|c|}
\hline & \multirow{2}{*}{\multicolumn{2}{|c|}{$\begin{array}{c}\begin{array}{c}\text { Group Onshore } \\
\text { Wind }(\boldsymbol{n}=\mathbf{2 0 0})\end{array} \\
\begin{array}{c}\text { Partial proportional } \\
\text { odds model }\end{array}\end{array}$}} & \multirow{2}{*}{\multicolumn{2}{|c|}{$\begin{array}{c}\text { Group Offshore } \\
\text { Wind }(n=200) \\
\begin{array}{c}\text { Proportional odds } \\
\text { model }\end{array}\end{array}$}} & \multirow{2}{*}{\multicolumn{2}{|c|}{$\begin{array}{c}\text { Group } \\
\begin{array}{c}\text { Waste-to-Energy } \\
(\boldsymbol{n}=\mathbf{1 6 1})\end{array} \\
\begin{array}{c}\text { Proportional odds } \\
\text { model }\end{array}\end{array}$}} & \multirow{2}{*}{\multicolumn{2}{|c|}{$\begin{array}{c}\begin{array}{c}\text { Group Biomass } \\
(n=210)\end{array} \\
\begin{array}{c}\text { Proportional odds } \\
\text { model }\end{array}\end{array}$}} \\
\hline & & & & & & & & \\
\hline \multirow[t]{2}{*}{ Pseudo $R^{2}$ (Nagelkerke) } & 0.482 & & 0.305 & & 0.427 & & 0.352 & \\
\hline & Estimate & Sig. & Estimate & Sig. & Estimate & Sig. & Estimate & Sig. \\
\hline \multicolumn{9}{|l|}{ Socio-economic characteristics } \\
\hline Gender (reference: female) & -0.338 & 0.242 & -0.028 & 0.935 & 0.101 & 0.791 & -0.348 & 0.222 \\
\hline Age & 0.007 & 0.347 & 0.012 & 0.200 & -0.023 & 0.141 & -0.027 & $\underline{0.002}$ \\
\hline \multicolumn{9}{|l|}{ Education (reference: education at tertiary level) } \\
\hline Lower secondary education or lower & $2.131 *$ & $\underline{0.026}$ & 0.882 & 0.087 & 0.652 & 0.336 & 0.700 & 0.099 \\
\hline Higher secondary education & $\overline{1.017^{*}}$ & $\overline{0.077}$ & 0.242 & 0.513 & 0.057 & 0.894 & 0.399 & 0.199 \\
\hline \multicolumn{9}{|l|}{ Neighborhood characteristics (reference: urban) } \\
\hline Semi-urban & -0.565 & 0.177 & -1.284 & 0.234 & -1.457 & $\underline{0.046}$ & $\underline{1.580}$ & $\underline{0.014}$ \\
\hline Suburban & -0.149 & 0.721 & 0.438 & 0.398 & $\overline{-1.208}$ & $\overline{0.062}$ & $\overline{1.223}$ & $\overline{0.067}$ \\
\hline Rural & -0.450 & 0.275 & & & -3.372 & $\underline{0.001}$ & $\underline{1.841}$ & $\underline{0.003}$ \\
\hline Home ownership structure (reference: owning home) & -0.246 & 0.528 & -0.034 & 0.939 & $\overline{-0.777}$ & $\overline{0.168}$ & $\overline{1.256}$ & $\underline{0.007}$ \\
\hline $\begin{array}{l}\text { Proximity (reference: power plant in close } \\
\text { proximity) }\end{array}$ & 0.263 & 0.286 & -0.054 & 0.881 & -0.277 & 0.641 & 0.210 & 0.464 \\
\hline Willingness to adapt to energy transition & -0.215 & $\underline{0.039}$ & 0.212 & 0.215 & $\underline{0.515}$ & $\underline{0.038}$ & 0.017 & 0.911 \\
\hline Knowledge about electricity production in Belgium & $\overline{0.002}$ & $\overline{0.981}$ & -0.137 & 0.324 & $\overline{0.237}$ & $\overline{0.167}$ & 0.097 & 0.398 \\
\hline \multicolumn{9}{|c|}{ Personal evaluation of the impact on life quality and economy } \\
\hline Development of local economy & $\underline{0.328}$ & $\underline{0.003}$ & -0.027 & 0.872 & 0.164 & 0.365 & $\underline{0.532}$ & $\underline{0.001}$ \\
\hline Development of house prices & $\overline{0.451}$ & $\overline{0.017}$ & -0.297 & 0.262 & 0.018 & 0.929 & $\overline{-0.065}$ & $\overline{0.715}$ \\
\hline Population health and safety & $\overline{0.173}$ & $\overline{0.327}$ & 0.303 & 0.291 & $\underline{0.563}$ & $\underline{0.027}$ & $\underline{0.438}$ & 0.039 \\
\hline Impact on living environment & 0.009 & 0.934 & -0.264 & 0.163 & $\overline{0.210}$ & $\overline{0.329}$ & $\overline{-0.311}$ & $\overline{0.075}$ \\
\hline \multicolumn{9}{|l|}{ Personal evaluation of landscape impact } \\
\hline Impact on landscape attachment & $-1.154^{*}$ & $\underline{0.000}$ & -0.445 & $\underline{0.017}$ & -0.518 & $\underline{0.012}$ & -0.450 & $\underline{0.013}$ \\
\hline Impact on landscape aesthetics & $\overline{0.162}$ & $\overline{0.185}$ & -0.781 & $\underline{0.000}$ & -0.322 & $\overline{0.174}$ & -0.009 & $\overline{0.952}$ \\
\hline Impact on recreational value of landscape & -0.263 & 0.113 & $\overline{0.131}$ & $\overline{0.479}$ & $\underline{-0.771}$ & $\underline{0.000}$ & 0.065 & 0.705 \\
\hline
\end{tabular}

The level of education proved to be a strong predictor, but this result needs to be interpreted with caution. The result that participants with lower education show a more positive attitude can be observed when there is a rather negative attitude, but it is not stable over all the levels of the dependent variable. Moreover, the difference between higher secondary education and university education is not significant, meaning that the effect is mainly true for a group with a maximum of a lower secondary education degree.

In the onshore wind group, a positive economic development and positive development of house prices both predict a positive attitude towards wind technology. Considering that in this group, $47 \%$ of the participants experienced the development of house prices as negative (see Figure 4), this aspect can be damaging to the overall image of wind energy and can be a cause for opposition. The same was true for compromising the feeling of landscape attachment in the community. The model also showed that the willingness to adapt to the energy transition was a significant negative predictor. This is counterintuitive considering that the usually observed effect is that a strong willingness to adapt one's lifestyle goes along with a positive attitude towards the technology [70]. Further investigation showed that the negative coefficient is not due to the relationship with the dependent variable but due to the relationship between predictors. A significant correlation (0.411, $p<0.001$ ) between the willingness to adapt and the experienced impact on landscape attachment was found. This does not undermine the model but rather calls for a careful interpretation of the willingness-to-adapt coefficient.

In the offshore wind model, people experiencing the aesthetic impact as strongly negative had higher odds of having generally a negative attitude towards the technology. This is not a surprising result, knowing that opposition against wind turbines is strongly connected to visual impacts [19,71]. However, aesthetics did not prove significant in the onshore wind group, although a majority of the participants in this group evaluated the 
aesthetic impacts to be negative, as can be expected from communities in the proximity of the wind parks. In the end, these negative experiences were not relevant for the general evaluation of the neighboring technology. Whether landscape impacts played a role in the technology evaluation also depended on the circumstances the technology is placed in. As Woods [65] pointed out, the population's evaluation varies depending on how rural landscape is understood, either as a place of spiritual activity or as a place of economic activity. This understanding of the landscape's function is also related to the personal connection of the population with the landscape, which was expressed in the presented models as the experienced impact on landscape attachment.

In both the waste-to-energy and the biomass group, the neighborhood characteristics proved to have a strong effect, although in different directions. While in the waste-toenergy case, participants living in non-urban environments had higher odds of showing a negative attitude towards the technology, the effect was reversed in the biomass case. Moreover, both models indicated the significant effect of the perceived health impact, i.e., negative experiences with regard to the health effects were predictors for a generally negative attitude towards the technology. This effect was observed for the two incineration technologies, while it was not significant in the wind energy models, where few participants experienced the technology as harmful to health or safety. Similar results were found by Zheng et al. [72] or Achillas et al. [73] to describe the commonly high levels of opposition against waste treatment and incineration plants. Although certain aspects of the energy plant were evaluated more negatively by the population living in close proximity, the distance was not a significant predictor for the technology attitude, i.e., the group living close to the waste-to-energy plant did not have a more negative attitude towards waste-toenergy plants in general. This can be supported by similar findings in the literature [73,74].

In the biomass case, additionally to the effect of neighborhood characteristics, the odds of a positive attitude increased when participants experienced a positive effect on the economy and local health as well as the feeling that their attachment to the locality was not compromised.

The attitude towards the technology did not significantly differ between the population sampled in close proximity with higher exposure to the power plant and the group located in the general neighborhood. Differences were only observed regarding the experienced impacts. In the case of the waste-to-energy group and the biomass group, it was observed that perceived impact on life quality and local economy significantly differed between the population living close to the plant compared with a group which is located further away; see Section 3.3. In the waste-to-energy group, the landscape impact was evaluated as significantly more negative by participants living in close proximity, which was not the case for the other RETs; see Section 3.4. The visibility of wind turbines from the place of residence (Group Close Proximity) did not lead to a more negative evaluation of the visual impact, in neither the onshore nor the offshore wind group. This finding is supported by Wolsink [67] who highlighted that the focus on visibility of infrastructure rather than on the personally experienced visual impact is a general shortcoming of centralized energy planning and entails low community acceptance of renewable energy infrastructure. The visual impact depends on the landscape in which the project is placed [63], which highlights the importance of not only assessing objective aesthetic criteria but also the personal connection to locations.

The commonality between the four models is the perceived negative impact on landscape attachment. This variable comprises the personal feeling of attachment and uniqueness of landscape identity. These are highly subjective factors which cannot be understood and assessed without engaging with the affected community. To address local opposition, it is thereby crucial to understand the attachment of the population to the altered landscape.

The concept of place attachment is commonly discussed in the literature with regard to energy projects with the majority of studies on the visual impact of wind energy $[63,75]$ and energy infrastructure [2]. A similarly detailed investigation for other types of projects and energy carriers is missing and could contribute to a broader discussion on the societal 
impact of energy landscapes. For the assessment of the landscape impact, the concept of Cultural Ecosystem Service was used to provide standardization where in the past individual approaches of impact quantification were used. While there are efforts to consider such cultural ecosystem service in energy planning [76,77], a quantification framework allowing the comparison of several project types and sites is still missing. The approach used in this paper can further contribute to the ecosystem services assessment of energy landscapes.

In the presented models, the experienced impacts play a more important role than the socio-economic characteristics of the population. The inclusion of experienced impacts as predictors in all models offered important explanations of how attitudes are formed. The effect of proximity, on the other hand, was not significant for the formation of the attitude and did not show in the overall regression model.

\section{Conclusions}

This research explores the public attitudes towards different RETs and how the population experiences the impacts of such technologies in their neighborhoods. Studies focusing on RET acceptance and attitudes mostly cover only one specific technology by using methods and scales adapted to each case. A direct comparison between these individual studies is thereby not feasible. A uniform survey design for energy project assessment is needed in order to establish a common basis for a comparison of RET types and energy landscapes. In this paper, a standardized survey was used for the comparison of experienced impacts and attitudes in four different energy neighborhoods of Flanders, Belgium. The case studies cover power generation plants using onshore wind, offshore wind, waste-to-energy, and biomass. In these four groups, first, the experienced impacts of the neighboring energy projects, and second, the attitude towards the neighboring RET, were assessed. By focusing on experienced impacts, the study aimed at the quantification of societal impacts due to land use for energy generation. The samples were further subdivided into people living close to the power plants and experiencing the impacts in close proximity to their home and people living in a distance but still in the same or neighboring towns. Moreover, the possible effect of personal experiences on the general attitude towards the neighboring technology was analyzed.

Overall, the survey results highlight that all technologies were perceived to contribute positively to economic development and job creation in the region. In the wind energy neighborhoods, the population reported a positive contribution to the population's health, while the waste-to-energy and the biomass groups perceive a slightly negative health impact due to the respective technologies. Here, a difference between people living in close proximity to the plant and the ones living further away was identified. People living in close proximity to the power plants experienced the health impact more negatively. The proximity did also have an effect on the perception of other disturbances, such as smell and increased traffic in the waste-to-energy and the biomass group. However, other neighborhood influences cannot be ruled out for the waste-to-energy group as the disturbance due to smell and traffic was reported to be more negative by participants living at greater distance.

Visual impacts on the landscape were evaluated more negatively in the onshore and offshore wind neighborhoods than for the other technologies. There was no difference in experienced severity of landscape impact for the group that lived in the line of sight of the wind park. As a range of methods and assessment framework are currently used to assess the magnitude of landscape impacts, a comparison of energy landscapes on a common scale is still rare. This study took the first step for a standardized landscape assessment. Rather than focusing on visibility only, the study investigated the underlying services provided by landscapes, i.e., aesthetics, landscape attachment, and reactional value.

This study thereby contributes to the comparability of energy neighborhoods, not only with regard to landscape impacts but also for the evaluation of local life quality impacts. The results can be used to deliberate about the development of energy neighborhoods and the impacts of different policy pathways for the communities living in these neighborhoods. 
The predictors of the attitude towards the neighboring energy technology, specifically the significance of personal experiences, were identified using ordinal logistic regression methods. The models showed that the severity of experienced impacts plays a significant role for people in forming a general attitude towards the technology. The negative experiences with one particular project were incorporated into the general attitude towards the technology. In particular, the impact on the personnel relationship to the landscape of the energy neighborhood was a significant predictor in all of the models. This supports the general notion put forward by Devine-Wright $[78]$ and many others $[69,75,79]$ that opposition against new energy projects is indeed not based on a simple NIMBY reaction but on the disturbance of personal connections to places. This poses a challenge for decisionmakers as the impact on landscape attachment is more difficult to predict than other, visible landscape changes. Therefore, public involvement methods are key in anticipating and predicting opposition that is based on internal processes and individual perceptions.

The results describe the situation in four specific Flemish energy neighborhoods. Further research is needed to incorporate the attitudes and experiences in other energy neighborhoods. Future studies could cover other RETs and other neighborhood characteristics, such as urban vs. rural environments, agricultural landscapes, or nature reserves but using a uniform questionnaire across a number of studies to allow a comparison. The scale used in this research for the assessment of landscape quality is based on the notion that land provides the population with cultural ecosystem services, and energy facilities impact the provision of these services positively or negatively. The specifics of land use for energy production are currently not well covered in ecosystem services research, and the incorporation of public experiences should be further investigated.

Moreover, post-installation experiences and attitudes presented in this research are not representative for pre-installation attitudes. A comparison of pre- and post-installation differences can provide important insights on how the perception changes over time. A more detailed categorization of the type of experience, i.e., level of interaction and time period people live in the neighborhood, would further contribute to the explanation of technology-specific attitudes.

The study shows the implications of RET exposure in so-called energy neighborhoods on the population. It was determined that personal experiences, positive and negative, affect the formation of post-construction attitudes towards different RETs. While the expansion of RETs will accelerate, as they are key in the strategy towards a low-carbon energy sector, the population is confronted with the implications of changing land use. The planning of energy transition pathways needs to incorporate the impacts on the locally affected population, including reduced quality of life as neighborhoods change due to energy generation. The quantification of experienced impacts on life quality and landscape is an important part to balance societal impacts against the requirements for achieving a low-carbon energy sector. After all, the study shows that beside expected disamenities that impact quality of life and landscape, there is also considerable support for RETs and appreciation of the benefits for the energy neighborhoods.

Author Contributions: Conceptualization, A.B., E.V., L.V.O. and J.D.; methodology, A.B., E.V. and L.V.O.; validation, A.B.; formal analysis, A.B.; investigation, A.B.; data curation, A.B.; writingoriginal draft preparation, A.B.; writing-review and editing, E.V., L.V.O. and J.D.; visualization, A.B.; supervision, E.V., L.V.O. and J.D.; project administration, A.B.; funding acquisition, E.V., L.V.O. and J.D. All authors have read and agreed to the published version of the manuscript.

Funding: This research was supported by the Special Research Fund (Bijzonder OnderzoeksfondsBOF) of Ghent University under grant agreement number BOF.24Y.2018.003.

Institutional Review Board Statement: Not applicable.

Informed Consent Statement: Informed consent was obtained from all subjects involved in the study.

Data Availability Statement: The data used in this study are available on request from the corresponding author. 
Acknowledgments: We thank Pieter De Pauw, Tjesney Mergaert, Justine Penneman and Hannes Polijn for their important work in conducting the case study surveys.

Conflicts of Interest: The authors declare no conflict of interest.

\section{Appendix A}

Table A1. Evaluation of experienced impact on local economy and health in the waste-to-energy and biomass neighborhoods-differentiation between people living close (Group Close Proximity) and the ones living further away (Group Neighborhood).

\begin{tabular}{|c|c|c|c|c|c|c|c|}
\hline & & $\begin{array}{c}\text { Very } \\
\text { Negative \% }\end{array}$ & $\begin{array}{c}\text { Negative } \\
\%\end{array}$ & $\begin{array}{c}\text { Neutral } \\
\%\end{array}$ & $\begin{array}{c}\text { Positive } \\
\%\end{array}$ & $\begin{array}{c}\text { Very } \\
\text { Positive \% }\end{array}$ & $p$-Value \\
\hline \multicolumn{8}{|c|}{ Contribution to local economy } \\
\hline \multirow{2}{*}{ Waste-to-Energy } & Group Close Proximity & 0.0 & 1.8 & 34.2 & 53.5 & 10.5 & \multirow[b]{2}{*}{0.885} \\
\hline & Group Neighborhood & 0.0 & 5.6 & 28.1 & 66.3 & 0.0 & \\
\hline \multirow{2}{*}{ Biomass } & Group Close Proximity & 3.2 & 6.1 & 41.3 & 45.9 & 3.5 & \multirow{2}{*}{0.288} \\
\hline & Group Neighborhood & 0.3 & 8.5 & 37.6 & 49.5 & 4.2 & \\
\hline \multicolumn{8}{|c|}{ Local job creation } \\
\hline \multirow{2}{*}{ Waste-to-Energy } & Group Close Proximity & 0.0 & 2.7 & 29.5 & 44.7 & 23.1 & \multirow{2}{*}{$0.019 *$} \\
\hline & Group Neighborhood & 0.0 & 4.6 & 36.1 & 59.2 & 0.0 & \\
\hline \multirow{2}{*}{ Biomass } & Group Close Proximity & 4.1 & 6.7 & 34.9 & 48.2 & 6.1 & \multirow{2}{*}{0.017 * } \\
\hline & Group Neighborhood & 0.3 & 3.3 & 25.7 & 61.0 & 9.7 & \\
\hline \multicolumn{8}{|c|}{ House prices (decreasing vs. increasing) } \\
\hline \multirow{2}{*}{ Waste-to-Energy } & Group Close Proximity & 5.7 & 23.7 & 41.6 & 15.7 & 13.4 & \multirow{2}{*}{0.896} \\
\hline & Group Neighborhood & 2.2 & 20.9 & 48.9 & 22.8 & 5.2 & \\
\hline \multirow{2}{*}{ Biomass } & Group Close Proximity & 18.8 & 46.7 & 32.4 & 2.2 & 0.0 & \multirow{2}{*}{0.742} \\
\hline & Group Neighborhood & 15.5 & 48.5 & 26.4 & 7.8 & 1.8 & \\
\hline \multicolumn{8}{|c|}{ Population health and safety } \\
\hline \multirow{2}{*}{ Waste-to-Energy } & Group Close Proximity & 9.4 & 31.6 & 45.2 & 11.8 & 2.1 & \multirow{2}{*}{0.004 * } \\
\hline & Group Neighborhood & 0.4 & 22.3 & 56.2 & 21.1 & 0.0 & \\
\hline \multirow{2}{*}{ Biomass } & Group Close Proximity & 11.5 & 22.7 & 56.3 & 6.1 & 3.5 & \multirow{2}{*}{0.028 * } \\
\hline & Group Neighborhood & 0.7 & 25.2 & 58.1 & 13.7 & 2.2 & \\
\hline
\end{tabular}

* significant at $p<0.05$

Table A2. Evaluation of experienced level of disturbance in the waste-to-energy and biomass neighborhoods—differentiation between people living close (Group Close Proximity) and the ones living further away (Group Neighborhood).

\begin{tabular}{|c|c|c|c|c|c|c|}
\hline & & $\begin{array}{c}\text { Very Negative } \\
\%\end{array}$ & Negative $\%$ & $\begin{array}{r}\text { Somewhat } \\
\text { Negative \% }\end{array}$ & No Impact & $p$-Value \\
\hline \multicolumn{7}{|c|}{ Disturbance due to noise } \\
\hline \multirow{2}{*}{ Waste-to-Energy } & Group Close Proximity & 3.2 & 3.4 & 29.9 & 63.5 & \multirow[b]{2}{*}{0.055} \\
\hline & Group Neighborhood & 0.0 & 11.1 & 37.8 & 51.2 & \\
\hline \multirow{2}{*}{ Biomass } & Group Close Proximity & 15.5 & 25.3 & 42.5 & 16.7 & \multirow{2}{*}{0.447} \\
\hline & Group Neighborhood & 7.8 & 31.3 & 38.7 & 22.2 & \\
\hline \multicolumn{7}{|c|}{ Disturbance due to smell } \\
\hline \multirow{2}{*}{ Waste-to-Energy } & Group Close Proximity & 6.2 & 11.6 & 41.3 & 41.0 & \multirow[b]{2}{*}{$0.033 *$} \\
\hline & Group Neighborhood & 0.0 & 26.4 & 48.6 & 25.0 & \\
\hline \multirow{2}{*}{ Biomass } & Group Close Proximity & 32.3 & 32.7 & 29.0 & 6.0 & \multirow{2}{*}{0.007 * } \\
\hline & Group Neighborhood & 13.4 & 39.8 & 30.8 & 16.0 & \\
\hline \multicolumn{7}{|c|}{ Disturbance due to increased traffic } \\
\hline \multirow{2}{*}{ Waste-to-Energy } & Group Close Proximity & 3.2 & 9.2 & 21.9 & 65.7 & \multirow[b]{2}{*}{$0.047 *$} \\
\hline & Group Neighborhood & 0.0 & 12.6 & 33.4 & 54.0 & \\
\hline \multirow{2}{*}{ Biomass } & Group Close Proximity & 20.7 & 39.0 & 31.0 & 9.4 & \multirow{2}{*}{0.108} \\
\hline & Group Neighborhood & 16.9 & 34.9 & 34.8 & 13.3 & \\
\hline
\end{tabular}


Table A3. Evaluation of experienced impact on landscape quality in the waste-to-energy and biomass groups-differentiation between people living close (Group Close Proximity) and the ones living further away (Group Neighborhood).

\begin{tabular}{|c|c|c|c|c|c|c|c|}
\hline Energy & Technology . & $\begin{array}{c}\text { Very } \\
\text { Negative \% }\end{array}$ & $\begin{array}{c}\text { Negative } \\
\%\end{array}$ & $\begin{array}{c}\text { Neutral } \\
\%\end{array}$ & $\begin{array}{c}\text { Positive } \\
\%\end{array}$ & $\begin{array}{c}\text { Very } \\
\text { Positive \% }\end{array}$ & $p$-Value \\
\hline \multicolumn{8}{|c|}{ reduces the feeling of attachment to the landscape } \\
\hline \multirow{2}{*}{ Waste-to-Energy } & Group Close Proximity & 1.8 & 15.3 & 44.0 & 32.6 & 6.2 & \multirow{2}{*}{$0 *$} \\
\hline & Group Neighborhood & 20.4 & 18.2 & 50.3 & 11.1 & 0.0 & \\
\hline \multirow{2}{*}{ Biomass } & Group Close Proximity & 7.8 & 24.6 & 47.6 & 17.4 & 2.6 & \multirow{2}{*}{0.84} \\
\hline & Group Neighborhood & 10.3 & 18.3 & 50.6 & 17.6 & 3.2 & \\
\hline \multicolumn{8}{|c|}{ does not symbolize a future-oriented development } \\
\hline \multirow{2}{*}{ Waste-to-Energy } & Group Close Proximity & 0.0 & 4.7 & 71.4 & 17.8 & 6.1 & \multirow[b]{2}{*}{0.004 * } \\
\hline & Group Neighborhood & 7.4 & 14.4 & 58.3 & 16.9 & 3.0 & \\
\hline \multirow{2}{*}{ Biomass } & Group Close Proximity & 1.0 & 23.2 & 38.3 & 22.9 & 14.7 & \multirow{2}{*}{0.115} \\
\hline & Group Neighborhood & 2.4 & 29.6 & 38.6 & 24.3 & 5.1 & \\
\hline \multicolumn{8}{|c|}{ changes the landscape identity of the region } \\
\hline \multirow{2}{*}{ Waste-to-Energy } & Group Close Proximity & 0.0 & 3.3 & 45.6 & 43.5 & 7.5 & \multirow[b]{2}{*}{0.145} \\
\hline & Group Neighborhood & 2.0 & 4.7 & 59.5 & 26.0 & 7.9 & \\
\hline \multirow{2}{*}{ Biomass } & Group Close Proximity & 0.0 & 12.4 & 38.6 & 34.0 & 14.9 & \multirow{2}{*}{0.116} \\
\hline & Group Neighborhood & 0.9 & 18.8 & 36.2 & 31.4 & 12.7 & \\
\hline \multicolumn{8}{|c|}{ does not add to the uniqueness of landscape } \\
\hline \multirow{2}{*}{ Waste-to-Energy } & Group Close Proximity & 0.0 & 11.0 & 46.0 & 38.5 & 4.5 & \multirow{2}{*}{0.972} \\
\hline & Group Neighborhood & 6.8 & 10.0 & 42.0 & 34.1 & 7.1 & \\
\hline \multirow[b]{2}{*}{ Biomass } & Group Close Proximity & 6.1 & 2.9 & 26.3 & 38.9 & 25.8 & \multirow{2}{*}{0.213} \\
\hline & Group Neighborhood & 4.2 & 2.4 & 24.9 & 50.3 & 18.1 & \\
\hline \multicolumn{8}{|c|}{ adds an artificial quality to the landscape } \\
\hline \multirow{2}{*}{ Waste-to-Energy } & Group Close Proximity & 1.3 & 8.7 & 43.0 & 32.6 & 14.4 & \\
\hline & Group Neighborhood & 10.7 & 11.6 & 38.0 & 37.9 & 1.7 & 0.107 \\
\hline & Group Close Proximity & 7.7 & 10.3 & 32.2 & 45.1 & 4.8 & \\
\hline Biomass & Group Neighborhood & 4.5 & 13.2 & 39.6 & 39.6 & 3.0 & 0.511 \\
\hline causes untouched & nature to be lost & & & & & & \\
\hline Waste-to-Fneroy & Group Close Proximity & 1.6 & 20.5 & 45.6 & 26.4 & 5.9 & \\
\hline Waste-to-Energy & Group Neighborhood & 7.3 & 7.2 & 37.8 & 41.2 & 6.5 & 0.527 \\
\hline & Group Close Proximity & 6.4 & 24.8 & 23.9 & 33.9 & 11.0 & \\
\hline Biomass & Group Neighborhood & 3.3 & 22.7 & 23.1 & 47.2 & 3.8 & 0.878 \\
\hline reduces the possi & ilities for recreational act & ties & & & & & \\
\hline & Group Close Proximity & 0.0 & 1.6 & 21.2 & 60.4 & 16.7 & \\
\hline Waste-to-Energy & Group Neighborhood & 7.3 & 6.4 & 58.8 & 21.6 & 5.9 & 0 * \\
\hline & Group Close Proximity & 0.9 & 12.2 & 40.4 & 31.3 & 15.2 & \\
\hline Biomass & Group Neighborhood & 1.8 & 12.9 & 54.3 & 27.7 & 3.4 & 0.011 * \\
\hline prevents free tim & activities in the vicinity & & & & & & \\
\hline Waste-to- & Group Close Proximity & 31.6 & 45.5 & 18.3 & 4.5 & 0.0 & \\
\hline Waste-to-Energy & Group Neighborhood & 13.7 & 38.9 & 39.2 & 4.7 & 3.5 & $0^{*}$ \\
\hline & Group Close Proximity & 6.2 & 37.6 & 30.3 & 18.5 & 7.4 & \\
\hline Biomass & Group Neighborhood & 8.5 & 37.2 & 35.4 & 16.2 & 2.7 & 0.392 \\
\hline impacts my abili & to relax & & & & & & \\
\hline & Group Close Proximity & 24.9 & 55.7 & 14.0 & 2.2 & 3.2 & \\
\hline Waste-to-Energy & Group Neighborhood & 8.5 & 38.3 & 45.5 & 7.7 & 0.0 & 0 * \\
\hline & Group Close Proximity & 3.7 & 30.0 & 39.7 & 25.1 & 1.5 & \\
\hline Biomass & Group Neighborhood & 10.1 & 25.3 & 47.5 & 16.8 & 0.3 & 0.789 \\
\hline
\end{tabular}


Table A4. Proportional odds model and partial proportional odds model for general attitude towards offshore wind energy.

\begin{tabular}{|c|c|c|c|c|c|c|c|}
\hline \multirow[t]{2}{*}{ Group Offshore Wind } & \multicolumn{3}{|c|}{ Proportional Odds Model } & \multicolumn{4}{|c|}{ Partial Proportional Odds Model } \\
\hline & Coef. & Sig. & $\begin{array}{c}\text { Proportional } \\
\text { Odds Test (Brant) }\end{array}$ & $\begin{array}{l}\text { SD vs. D, N, } \\
\text { A, SA Coef. }\end{array}$ & $\begin{array}{l}\text { SD, D vs. N, } \\
\text { A, SA Coef. }\end{array}$ & $\begin{array}{l}\text { SD, D, N vs. } \\
\text { A, SA Coef. }\end{array}$ & $\begin{array}{l}\text { SD, D, N, A } \\
\text { vs. SA Coef. }\end{array}$ \\
\hline \multicolumn{8}{|l|}{ Socio-economic characteristics } \\
\hline Gender (reference: female) & -0.474 & 0.184 & 0.935 & -0.338 & & & \\
\hline Age & 0.009 & 0.387 & 0.998 & 0.007 & & & \\
\hline \multicolumn{8}{|c|}{ Education (reference: education at tertiary level) } \\
\hline $\begin{array}{l}\text { Lower secondary education or } \\
\text { lower }\end{array}$ & -0.343 & 0.424 & 0.020 & $2.131 *$ & 0.494 & $-1.267^{*}$ & 0.041 \\
\hline Higher secondary education & -0.331 & 0.369 & 0.607 & 1.017 & -0.089 & -0.350 & -0.138 \\
\hline \multicolumn{8}{|c|}{ Neighborhood characteristics (reference: urban) } \\
\hline Semi-urban & -0.666 & 0.164 & 0.656 & -0.565 & & & \\
\hline Suburban & -0.083 & 0.858 & 0.162 & -0.149 & & & \\
\hline Rural & -0.872 & 0.065 & 0.666 & -0.450 & & & \\
\hline $\begin{array}{l}\text { Home ownership structure } \\
\text { (reference: owning home) }\end{array}$ & -0.433 & 0.295 & 0.613 & -0.246 & & & \\
\hline $\begin{array}{l}\text { Proximity (reference: power plant } \\
\text { in close proximity) }\end{array}$ & 0.428 & 0.179 & 0.359 & 0.263 & & & \\
\hline $\begin{array}{l}\text { Willingness to adapt to energy } \\
\text { transition }\end{array}$ & -0.31 & 0.060 & 0.590 & $-0.215^{*}$ & & & \\
\hline $\begin{array}{l}\text { Knowledge about electricity } \\
\text { production in Belgium }\end{array}$ & -0.047 & 0.699 & 0.463 & 0.002 & & & \\
\hline \multicolumn{8}{|c|}{ Personal evaluation of the impact on life quality and economy } \\
\hline Development of local economy & $0.393 *$ & 0.044 & 0.844 & $0.328 *$ & & & \\
\hline Development of house prices & $0.65 *$ & 0.012 & 0.418 & $0.451 *$ & & & \\
\hline Population health and safety & $0.463 *$ & 0.042 & 0.820 & 0.173 & & & \\
\hline Impact on living environment & -0.009 & 0.957 & 0.701 & 0.009 & & & \\
\hline \multicolumn{8}{|c|}{ Personal evaluation of landscape impact } \\
\hline Impact on landscape attachment & $\begin{array}{l}-0.978 \\
*\end{array}$ & 0.000 & 0.075 & $-1.154 *$ & $-0.808^{*}$ & $-0.704 *$ & $-0.502 *$ \\
\hline Impact on landscape aesthetics & 0.236 & 0.272 & 0.244 & 0.162 & & & \\
\hline $\begin{array}{l}\text { Impact on recreational value of } \\
\text { landscape }\end{array}$ & $\begin{array}{l}-0.419 \\
*\end{array}$ & 0.046 & 0.925 & -0.263 & & & \\
\hline
\end{tabular}

${ }^{*}$ significant at $p<0.05$. SD . . s strongly disagree, A . . agree, $\mathrm{N} \ldots$ neutral, A . . agree, SA . . strongly agree.

\section{References}

1. European Commission. European Commission Communication from the Commission to the European Parliament, the European Council, the Council, the European Economic and Social Committee and the Committee of the Regions. The European Green Deal; COM/2019/640 Final; European Commission: Brussels, Belgium, 2019.

2. Devine-Wright, P.; Batel, S. My neighbourhood, my country or my planet? The influence of multiple place attachments and climate change concern on social acceptance of energy infrastructure. Glob. Environ. Chang. 2017, 47, 110-120. [CrossRef]

3. Bridge, G.; Bouzarovski, S.; Bradshaw, M.; Eyre, N. Geographies of energy transition: Space, place and the low-carbon economy. Energy Policy 2013, 53, 331-340. [CrossRef]

4. Bertsch, V.; Hall, M.; Weinhardt, C.; Fichtner, W. Public acceptance and preferences related to renewable energy and grid expansion policy: Empirical insights for Germany. Energy 2016, 114, 465-477. [CrossRef]

5. Bulavskaya, T.; Reynès, F. Job creation and economic impact of renewable energy in the Netherlands. Renew. Energy 2018, 119, 528-538. [CrossRef]

6. Sulich, A.; Rutkowska, M.; Popławski, L. Green jobs, definitional issues, and the employment of young people: An analysis of three European Union countries. J. Environ. Manag. 2020, 262, 110314. [CrossRef]

7. Kost, C.; Brandes, J.; Senkpiel, C.; Sterchele, P.; Wrede, D.; Henning, H.M. Modeling of persistence, non-acceptance and sufficiency in long-term energy scenarios for Germany. Energies 2021, 14, 4484. [CrossRef]

8. Giordono, L.S.; Boudet, H.S.; Karmazina, A.; Taylor, C.L.; Steel, B.S. Opposition “overblown”? Community response to wind energy siting in the Western United States. Energy Res. Soc. Sci. 2018, 43, 119-131. [CrossRef]

9. Batel, S.; Devine-Wright, P.; Tangeland, T. Social acceptance of low carbon energy and associated infrastructures: A critical discussion. Energy Policy 2013, 58, 1-5. [CrossRef]

10. Sengers, F.; Raven, R.P.J.M.; Van Venrooij, A. From riches to rags: Biofuels, media discourses, and resistance to sustainable energy technologies. Energy Policy 2010, 38, 5013-5027. [CrossRef]

11. Buchmayr, A.; Verhofstadt, E.; Van Ootegem, L.; Sanjuan Delmás, D.; Thomassen, G.; Dewulf, J. The path to sustainable energy supply systems: Proposal of an integrative sustainability assessment framework. Renew. Sustain. Energy Rev. 2021, 138, 110666. [CrossRef]

12. Perlaviciute, G.; Steg, L. The influence of values on evaluations of energy alternatives. Renew. Energy 2015, 77, 259-267. [CrossRef] 
13. Thøgersen, J.; Noblet, C. Does green consumerism increase the acceptance of wind power? Energy Policy 2012, 51, 854-862. [CrossRef]

14. Roddis, P.; Carver, S.; Dallimer, M.; Norman, P.; Ziv, G. The role of community acceptance in planning outcomes for onshore wind and solar farms: An energy justice analysis. Appl. Energy 2018, 226, 353-364. [CrossRef]

15. Bidwell, D. The role of values in public beliefs and attitudes towards commercial wind energy. Energy Policy 2013, 58, 189-199. [CrossRef]

16. Jones, C.R.; Richard Eiser, J. Understanding "local" opposition to wind development in the UK: How big is a backyard? Energy Policy 2010, 38, 3106-3117. [CrossRef]

17. Wolsink, M. Wind power and the NIMBY-myth: Institutional capacity and the limited significance of public support. Renew. Energy 2000, 21, 49-64. [CrossRef]

18. Wüstenhagen, R.; Wolsink, M.; Bürer, M.J. Social acceptance of renewable energy innovation: An introduction to the concept. Energy Policy 2007, 35, 2683-2691. [CrossRef]

19. Betakova, V.; Vojar, J.; Sklenicka, P. Wind turbines location: How many and how far? Appl. Energy 2015, 151, 23-31. [CrossRef]

20. Molnarova, K.; Sklenicka, P.; Stiborek, J.; Svobodova, K.; Salek, M.; Brabec, E. Visual preferences for wind turbines: Location, numbers and respondent characteristics. Appl. Energy 2012, 92, 269-278. [CrossRef]

21. Ladenburg, J.; Dahlgaard, J.O. Attitudes, threshold levels and cumulative effects of the daily wind-turbine encounters. Appl. Energy 2012, 98, 40-46. [CrossRef]

22. Scognamiglio, A. "Photovoltaic landscapes": Design and assessment. A critical review for a new transdisciplinary design vision. Renew. Sustain. Energy Rev. 2016, 55, 629-661. [CrossRef]

23. Sherren, K.; Beckley, T.M.; Parkins, J.R.; Stedman, R.C.; Keilty, K.; Morin, I. Learning (or living) to love the landscapes of hydroelectricity in Canada: Eliciting local perspectives on the Mactaquac Dam via headpond boat tours. Energy Res. Soc. Sci. 2016, 14, 102-110. [CrossRef]

24. Arnaiz, M.; Cochrane, T.A.; Hastie, R.; Bellen, C. Micro-hydropower impact on communities' livelihood analysed with the capability approach. Energy Sustain. Dev. 2018, 45, 206-210. [CrossRef]

25. Devine-Wright, P. Place attachment and public acceptance of renewable energy: A tidal energy case study. J. Environ. Psychol. 2011, 31, 336-343. [CrossRef]

26. Upreti, B.R.; Van Der Horst, D. National renewable energy policy and local opposition in the UK: The failed development of a biomass electricity plant. Biomass Bioenergy 2004, 26, 61-69. [CrossRef]

27. Langer, K.; Decker, T.; Roosen, J.; Menrad, K. A qualitative analysis to understand the acceptance of wind energy in Bavaria. Renew. Sustain. Energy Rev. 2016, 64, 248-259. [CrossRef]

28. Lucas, H.; Carbajo, R.; Machiba, T.; Zhukov, E.; Cabeza, L.F. Improving Public Attitude towards Renewable Energy. Energies 2021, 14, 4521. [CrossRef]

29. Burningham, K.; Barnett, J.; Walker, G. An Array of Deficits: Unpacking NIMBY Discourses in Wind Energy Developers' Conceptualizations of Their Local Opponents. Soc. Nat. Resour. 2015, 28, 246-260. [CrossRef]

30. Mayer, A.; Hazboun, S.O.; Howe, P.D. For the love of sun and wind? Proximity to renewable energy facilities and support for renewable power across time and space in the United States. Energy Res. Soc. Sci. 2021, 73, 101910. [CrossRef]

31. Bauwens, T.; Devine-Wright, P. Positive energies? An empirical study of community energy participation and attitudes to renewable energy. Energy Policy 2018, 118, 612-625. [CrossRef]

32. van der Horst, D. NIMBY or not? Exploring the relevance of location and the politics of voiced opinions in renewable energy siting controversies. Energy Policy 2007, 35, 2705-2714. [CrossRef]

33. Delicado, A.; Figueiredo, E.; Silva, L. Community perceptions of renewable energies in Portugal: Impacts on environment, landscape and local development. Energy Res. Soc. Sci. 2016, 13, 84-93. [CrossRef]

34. Sharpton, T.; Lawrence, T.; Hall, M. Drivers and barriers to public acceptance of future energy sources and grid expansion in the United States. Renew. Sustain. Energy Rev. 2020, 126, 109826. [CrossRef]

35. Wolsink, M. Framing in renewable energy policies: A glossary. Energies 2020, 13, 2871. [CrossRef]

36. Wolsink, M. Undesired reinforcement of harmful 'self-evident truths' concerning the implementation of wind power. Energy Policy 2012, 48, 83-87. [CrossRef]

37. Hoen, B.; Wiser, R.; Cappers, P.; Thayer, M.; Sethi, G. Wind energy facilities and properties: The effect of proximity and view on sales prices. J. Real Estate Res. 2011, 33, 279-316. [CrossRef]

38. Lilley, M.B.; Firestone, J.; Kempton, W. The effect of wind power installations on coastal tourism. Energies 2010, 3, 1-22. [CrossRef]

39. Wrózyński, R.; Sojka, M.; Pyszny, K. The application of GIS and 3D graphic software to visual impact assessment of wind turbines. Renew. Energy 2016, 96, 625-635. [CrossRef]

40. Truelove, H.B. Energy source perceptions and policy support: Image associations, emotional evaluations, and cognitive beliefs. Energy Policy 2012, 45, 478-489. [CrossRef]

41. Firestone, J.; Kirk, H. A strong relative preference for wind turbines in the United States among those who live near them. Nat. Energy 2019, 4, 311-320. [CrossRef]

42. Ribeiro, F.; Ferreira, P.; Araújo, M.; Braga, A.C. Modelling perception and attitudes towards renewable energy technologies. Renew. Energy 2018, 122, 688-697. [CrossRef] 
43. EU. 2018/2001 of the European Parliament and of the Council of 11 December 2018 on the promotion of the use of energy from renewable sources. Off. J. Eur. Union 2018, L328, 82-209.

44. Vlaamse Regering Vlaams Energie- en Klimaatplan 2021-2030. Available online: https://publicaties.vlaanderen.be/view-file/35 658 (accessed on 24 February 2021).

45. Lumley, T. Complex Surveys: A Guide to Analysis Using R; John Wiley \& Sons Inc.: Hoboken, NJ, USA, 2010; ISBN 111821093X.

46. R Core Team. R: A Language and Environment for Statistical Computing; R Core Team: Vienna, Austria, 2020.

47. Bohner, G.; Dickel, N. Attitudes and attitude change. Annu. Rev. Psychol. 2011, 62, 391-417. [CrossRef] [PubMed]

48. Crano, W.D.; Prislin, R. Attitudes and Persuasion. Annu. Rev. Psychol. 2006, 57, 345-374. [CrossRef]

49. Thurstone, L.L. The Vectors of Mind: Multiple-Factor Analysis for the Isolation of Primary Traits; University of Chicago Press: Chicago, IL, USA, 1935.

50. McCullagh, P. Regression Models for Ordinal Data. J. R. Stat. Soc. Ser. B 1980, 42, 109-142. [CrossRef]

51. Williams, R. Generalized ordered logit/partial proportional odds models for ordinal dependent variables. Stata J. 2006, 6, 58-82. [CrossRef]

52. Brant, R. Assessing Proportionality in the Proportional Odds Model for Ordinal Logistic Regression. Biometrics 1990, 46, 1171-1178. [CrossRef] [PubMed]

53. Alberini, A.; Bigano, A.; Ščasný, M.; Zvěřinová, I. Preferences for Energy Efficiency vs. Renewables: What Is the Willingness to Pay to Reduce CO2 Emissions? Ecol. Econ. 2018, 144, 171-185. [CrossRef]

54. Zografakis, N.; Sifaki, E.; Pagalou, M.; Nikitaki, G.; Psarakis, V.; Tsagarakis, K.P. Assessment of public acceptance and willingness to pay for renewable energy sources in Crete. Renew. Sustain. Energy Rev. 2010, 14, 1088-1095. [CrossRef]

55. Bergmann, A.; Hanley, N.; Wright, R. Valuing the attributes of renewable energy investments. Energy Policy 2006, 34, 1004-1014. [CrossRef]

56. Stigka, E.K.; Paravantis, J.A.; Mihalakakou, G.K. Social acceptance of renewable energy sources: A review of contingent valuation applications. Renew. Sustain. Energy Rev. 2014, 32, 100-106. [CrossRef]

57. Dröes, M.I.; Koster, H.R.A. Renewable energy and negative externalities: The effect of wind turbines on house prices. J. Urban Econ. 2016, 96, 121-141. [CrossRef]

58. Sunak, Y.; Madlener, R. The impact of wind farm visibility on property values: A spatial difference-in-differences analysis. Energy Econ. 2016, 55, 79-91. [CrossRef]

59. Mueller, C.E.; Keil, S.I.; Bauer, C. Effects of spatial proximity to proposed high-voltage transmission lines: Evidence from a natural experiment in Lower Saxony. Energy Policy 2017, 111, 137-147. [CrossRef]

60. Wolsink, M.; Devilee, J. The motives for accepting or rejecting waste infrastructure facilities. Shifting the focus from the planners' perspective to fairness and community commitment. J. Environ. Plan. Manag. 2009, 52, 217-236. [CrossRef]

61. Haines-Young, R.; Potschin, M.B. Common International Classification of Ecosystem Services (CICES) V5.1 and guidance on the application of the revised structure. One EcoSyst. 2018, 3, e27108. [CrossRef]

62. Grontmij Studieopdracht-Monitoring van de Effecten van Far-Shore Windmolenparken op Het Landschap-Deel SocioLandschappelijk Onderzoek; Study on Behalf of BMM: Gent. 2010. Available online: https://odnature.naturalsciences.be/ downloads/mumm/windfarms/258468_eindrapport_29062010_ava_plus_bijlagen.pdf (accessed on 12 September 2021).

63. Devine-Wright, P.; Howes, Y. Disruption to place attachment and the protection of restorative environments: A wind energy case study. J. Environ. Psychol. 2010, 30, 271-280. [CrossRef]

64. Selman, P. Learning to Love the Landscapes of Carbon- Neutrality. Landsc. Res. 2010, 35, 157-171. [CrossRef]

65. Woods, M. Conflicting Environmental Visions of the Rural: Windfarm Development in Mid Wales. Sociol. Rural. 2003, 43, 271-288. [CrossRef]

66. Ioannidis, R.; Koutsoyiannis, D. A review of land use, visibility and public perception of renewable energy in the context of landscape impact. Appl. Energy 2020, 276, 115367. [CrossRef]

67. Wolsink, M. Co-production in distributed generation: Renewable energy and creating space for fitting infrastructure within landscapes. Landsc. Res. 2018, 43, 542-561. [CrossRef]

68. Bertsch, V.; Hyland, M.; Mahony, M. What drives people's opinions of electricity infrastructure? Empirical evidence from Ireland. Energy Policy 2017, 106, 472-497. [CrossRef]

69. Johansen, K. Local support for renewable energy technologies? Attitudes towards local near-shore wind farms among second home owners and permanent area residents on the Danish coast. Energy Policy 2019, 132, 691-701. [CrossRef]

70. Hobman, E.V.; Ashworth, P. Public support for energy sources and related technologies: The impact of simple information provision. Energy Policy 2013, 63, 862-869. [CrossRef]

71. Firestone, J.; Bates, A.; Knapp, L.A. See me, Feel me, Touch me, Heal me: Wind turbines, culture, landscapes, and sound impressions. Land Use Policy 2015, 46, 241-249. [CrossRef]

72. Zheng, J.; Yu, L.; Ma, G.; Mi, H.; Jiao, Y. Residents' acceptance towards waste-to-energy facilities: Formation, diffusion and policy implications. J. Clean. Prod. 2021, 287, 125560. [CrossRef]

73. Achillas, C.; Vlachokostas, C.; Moussiopoulos, N.; Banias, G.; Kafetzopoulos, G.; Karagiannidis, A. Social acceptance for the development of a waste-to-energy plant in an urban area. Resour. Conserv. Recycl. 2011, 55, 857-863. [CrossRef]

74. Baxter, J.; Ho, Y.; Rollins, Y.; Maclaren, V. Attitudes toward waste to energy facilities and impacts on diversion in Ontario, Canada. Waste Manag. 2016, 50, 75-85. [CrossRef] 
75. Lindén, A.; Rapeli, L.; Brutemark, A. Community attachment and municipal economy: Public attitudes towards wind power in a local context. Environ. Sci. Policy 2015, 54, 10-14. [CrossRef]

76. Hastik, R.; Basso, S.; Geitner, C.; Haida, C.; Poljanec, A.; Portaccio, A.; Vrščaj, B.; Walzer, C. Renewable energies and ecosystem service impacts. Renew. Sustain. Energy Rev. 2015, 48, 608-623. [CrossRef]

77. Picchi, P.; van Lierop, M.; Geneletti, D.; Stremke, S. Advancing the relationship between renewable energy and ecosystem services for landscape planning and design: A literature review. Ecosyst. Serv. 2019, 35, 241-259. [CrossRef]

78. Devine-Wright, P. Rethinking NIMBYism: The role of place attachment and place identity in explaining place-protective action. J. Community Appl. Soc. Psychol. 2009, 19, 426-441. [CrossRef]

79. Liebe, U.; Dobers, G.M. Decomposing public support for energy policy: What drives acceptance of and intentions to protest against renewable energy expansion in Germany? Energy Res. Soc. Sci. 2019, 47, 247-260. [CrossRef] 